\title{
Antidiabetic Activities of Korean Red Pine (Pinus densiflora) Inner Bark Extracts ${ }^{1}$
}

\author{
Hee-Jeong $\mathrm{Min}^{2} \cdot$ Eun-Ji $\mathrm{Kim}^{3} \cdot$ Seong-whan Shinn $\mathbb{D}^{4, \dagger} \cdot$ Young-Soo Bae $\mathbb{D}^{2, \dagger}$
}

\begin{abstract}
This study was carried out to investigate the potential of Korean red pine (Pinus densiflora) inner bark extracts as an antidiabetic agent. The ethyl acetate soluble fraction of the bark extracts was chromatographed on a Sephadex LH-20 column to yield five compounds, which structures were elucidated by NMR spectroscopy. The isolated compounds were (+)-catehin, (-)-epicatechin, taxifolin, taxifolin-3'-O- $\beta$-D-(+)-glucose and $\tilde{n}$-courmaric acid. The antidiabetic activity of the different fractions, including the crude extracts and isolated compounds, was evaluated by $\beta$-cells insulin secretion and glucose uptake in skeletal muscle cells. The insulin secretion was $128 \%$ for taxifolin at $25 \mu \mathrm{g} / \mathrm{mL}$. However, the other samples had no effect on this test. For the glucose uptake activity assay, $1 \mu \mathrm{M}$ insulin and $2 \mathrm{mM}$ metformin were used as controls. Both the crude extract and taxifolin showed relatively low activity values, but the other samples yielded glucose uptake values over 260\%. $\rho$-courmaric acid showed the highest uptake (270\%). The results confirmed that Korean red pine extracts may be used as a hypoglycemic agent.
\end{abstract}

Keywords: Korean red pine (Pinus densiflora), inner bark, antidiabetic activities, $\beta$-cells insulin secretion, glucose uptake activity

\section{INTRODUCTION}

Diabetes is one of chronic diseases that threaten human health along with obesity and increasing every year. In particular, that is a metabolic disease which insulin secretion is not controlled and blood glucose is not regulated. It is divided into type I diabetes, type II diabetes, and gestational diabetes. Type I is insulin-dependent diabetes, which is unable to produce insulin, and is unable to produce insulin naturally $\beta$ -cells due to autoimmune disorders. Type II is caused by insulin resistance that cells do not respond to normal insulin action and is called non-insulin dependent (Eizirik and Mandrup-Poulsen, 2001; Miriam et al.,

${ }^{1}$ Date Received May 16, 2019, Date Accepted July 15, 2019

2 Department of Forest Biomaterials Engineering, College of Forest and Environmental Sciences, Kangwon National University, Chuncheon 24341, Republic of Korea

${ }^{3}$ Regional Strategic Industry Innovation Center, Hallym University, Chuncheon 24252, Republic of Korea

${ }^{4}$ Department of Advanced Materials and Chemical Engineering, Halla university, Wonju 26404, Republic of Korea

$\dagger$ Corresponding author: Young-Soo Bae (e-mail: bae@kangwon.ac.kr, ORCID: 0000-0003-1108-9269)

† Corresponding author: Seong-whan Shinn (e-mail: swshinn@halla.ac.kr, ORCID: 0000-0002-8511-5151) 
2005; choi et al., 2010). Currently diabetic patients have abnormally high level of glucose and insulin in the post prandial blood. However, they use various hypoglycemic agents to keep the blood glucose level within the normal range rather than the fundamental treatment. Due to the various side effects of synthetic hypoglycemic agents, recently researches on herbal medicines has been actively conducted (Heo et al., 2009; Standl and Schnell, 2012).

Free radicals and active oxygen are known to be detrimental to human health by damaging lipids, proteins, and nucleic acids, by causing oxidative stress, and by leading to aging and many geriatric diseases. Antioxidants remove free radicals through electron donation function (Aviram, 2000; Nono and Parola, 2008; Jung, et al., 2017; Jeong, et al., 2017; Kim, et al., 2017). Antioxidant activity is a very important part of antidiabetic efficacy because the oxidative stress is cause insulin secretion disorder by increasing $\beta$-cell damage in type $\mathbb{I}$ diabetes (Evans et al., 2002; Kim and Son, 2006).

Korean red pine (Pinus densiflora) belongs to the Pinaceae family and is widely distributed in Korea and in the other areas of East Asia (Kim, 1996). Needles, cones, bark, and pollen of Korean red pine have been used for medicine and safe food raw materials (Kim et al., 2012). Although many studies on the chemical components and biological activities have been reported on the extracts of Korean red pine leaves and branches, but the researches on the bark extracts have still plenty of room to be conducted. Also the antioxidative and antidiabetic activity on the active components of the pine bark have not been studied yet.

Therefore, this study was carried out to investigate the chemical constituents of the extracts of Korean red pine inner bark and to confirm the potential for functional application by the evaluation of antidiabetic activity of the extracts.

\section{MATERIALS and METHODS}

\subsection{General sample preparation}

Korean red pine inner bark $(2.11 \mathrm{~kg})$, collected at the experimental forest of Kangwon National University, was air-dried in the laboratory for about two weeks, ground to fine powder, extracted three times with $70 \%$ aqueous ethanol at room temperature, and then concentrated under vacuum pressure. The concentrated crude was sequentially fractionated with n-hexane, chloroform $\left(\mathrm{CHCl}_{3}\right)$, ethyl acetate (EtOAc) and $\mathrm{H}_{2} \mathrm{O}$ using a separatory funnel (Table 1). A portion of EtOAc soluble (5 g) of those fractions was repeatedly chromatographed on a Sephadex LH-20 column using various kinds of eluting solvents, several aqueous $\mathrm{MeOH}-\mathrm{H}_{2} \mathrm{O}, \mathrm{MeOH}-\mathrm{CHCl}_{3}$, and EtOH-hexane, to afford 5 isolated compounds. The structures of isolated compounds were characterized with NMR data using methanol- $d_{4}\left(\mathrm{CD}_{3} \mathrm{OD}\right)$ NMR solvent and a Bruker Avance DPX $600 \mathrm{MHz}$ spectroscopy at the central laboratory of Kangwon National University and then elucidated by NMR analysis and by comparison with the authentic literature data (Shinn et al., 2019; Foo and Karchesy, 1989; Harbone and Mabry, 1982; Ham and Bae, 1995; Ahn et al., 1996).

Then the crude, EtOAc soluble, $\mathrm{H}_{2} \mathrm{O}$ soluble, and the isolated compounds were treated to evaluate the antidiabetic activities. Each of the samples was dissolved in dimethy sulfoxide (DMSO, Sigma-Aldrich

Table 1. Weight of each fraction of Korean red pine inner bark extracts

\begin{tabular}{lr}
\hline Fractions & \multicolumn{1}{c}{ inner bark } \\
\hline \hline Crude & $173.4432 \mathrm{~g}(100 \%)$ \\
$n$-hexane soluble fraction & $4.8514 \mathrm{~g}(2.80 \%)$ \\
$\mathrm{CHCl}_{3}$ soluble fraction & $5.7743 \mathrm{~g}(3.33 \%)$ \\
EtOAc soluble fraction & $19.3563 \mathrm{~g}(11.16 \%)$ \\
$\mathrm{H}_{2} \mathrm{O}$ soluble fraction & $143.4521 \mathrm{~g}(82.71 \%)$ \\
\hline
\end{tabular}


Co.) to prepare a $100 \mathrm{mg} / \mathrm{mL}$ stock solution and then added into the cell culture medium according to the preset treating concentration for evaluation of antidiabetic activities.

\subsection{Evaluation of insulin secretion in HIT-T15 pancreatic $\beta$-cells}

\subsubsection{Cell culture}

HIT-T15 hamster pancreatic $\beta$-cells were purchased from the Korean Cell Bank (Seoul, Korea). HIT-T15 cells were cultured in Ham's F12K medium supplemented with $100 \mathrm{~mL} / \mathrm{L}$ horse serum, $25 \mathrm{~mL} / \mathrm{L}$ fetal bovine serum (FBS), 100,000 U/L penicillin, and 100 $\mathrm{mg} / \mathrm{L}$ streptomycin at $37^{\circ} \mathrm{C}$ in a humidified atmosphere of $5 \% \mathrm{CO}_{2}$. When cells were $80 \%$ confluent, they were subcultured using $0.25 \%$ trypsin-2.65 mM EDTA, and the medium was changed every 2 days.

\subsubsection{Cell viability assay}

Cell viability in HIT-T15 cells were estimated by the MTT assay (Denizot and Lang, 1986). The cytotoxicities of Korean red pine bark extracts on HIT-T15 cells were evaluated by MTT assay using the concentration of $0,1,5,10,25,50$ and $100 \mu \mathrm{g} / \mathrm{ml}$. HIT-T15 cells were plated at a density of $2 \times 10^{4}$ cells/well in a 96-well plate and incubated for $24 \mathrm{~h}$. After incubation for $24 \mathrm{~h}$, cells were treated with various concentrations of test samples for $24 \mathrm{~h}$. At the end of the treatment period, the media were removed and $1 \mathrm{mg} / \mathrm{mL}$ 3-(4,5-dimethyl thiazol-2-yl)-2,5-diphenyl tetrazolium bromide (MTT, Amresco, Solon, OH, USA) solution was added, and the cells were incubated at $37^{\circ} \mathrm{C}$ for $2 \mathrm{~h}$. After incubation for $2 \mathrm{~h}$, MTT solution was removed, $0.1 \mathrm{~mL}$ of isoporpanol was added to dissolve formazan crystals, and the absorbance was measured at $570 \mathrm{~nm}$ with a microplate reader (Molecular Devices, Sunnyvale, CA, USA).

\subsubsection{Evaluation of insulin secretion in HIT-T15 cells}

HIT-T15 cells were plated at a density of $5 \times 10^{4}$ cells/well in a 48-well plate and incubated for $48 \mathrm{~h}$. After incubation for $48 \mathrm{~h}$, cells were incubated in 1 mL Krebs-Ringer Bicarbonate Buffer (KRB buffer: 10 $\mathrm{mM}$ D-glucose, $0.49 \mathrm{mM} \mathrm{MgCl}_{2}, 119.78 \mathrm{mM} \mathrm{NaCl}$, $4.56 \mathrm{mM} \mathrm{KCl}, 0.7 \mathrm{mM} \mathrm{Na} \mathrm{HPO}_{4}, 1.3 \mathrm{mM} \mathrm{NaH} \mathrm{PO}_{4}$, $14.99 \mathrm{mM} \mathrm{NaHCO}$ ) supplemented with various concentration of test samples for $30 \mathrm{~min}$. Media conditioned for $30 \mathrm{~min}$ were collected and centrifuged at 12,000 rpm for $10 \mathrm{~min}$. The supernatant was collected and the levels of insulin in supernatant were assayed using the insulin ELISA kit (Shibayagi Co., Gunma, Japan) according to the manufacturer's instructions.

\subsection{Evaluation of glucose uptake in L6 skeletal muscle cells}

\subsubsection{Cell culture}

L6 rat skeletal muscle cells were purchased from the Korean Cell Bank (Seoul, Korea). L6 cells were cultured in Dulbecco Modified Eagle Medium (DMEM) supplemented with $100 \mathrm{~mL} / \mathrm{L}$ FBS, 100,000 U/L penicillin, and $100 \mathrm{mg} / \mathrm{L}$ streptomycin at $37^{\circ} \mathrm{C}$ in a humidified atmosphere of $5 \% \mathrm{CO}_{2}$. When cells were $80 \%$ confluent, they were subcultured using $0.25 \%$ trypsin-2.65 mM EDTA, and the medium was changed every 2 days.

\subsubsection{Cell viability assay}

L6 cells were plated at a density of $5 \times 10^{4}$ cells in a 48-well plate and incubated for $24 \mathrm{~h}$. After incubation for $24 \mathrm{~h}$, cells were treated with various concentrations of test samples for $24 \mathrm{~h}$. Cell viability were measured by MTT assay, as described above.

\subsubsection{Evaluation of glucose uptake in $L 6$ cells}

L6 cells were plated at a density of $1 \times 10^{4}$ cells/well in a 96-well plate and incubated for $24 \mathrm{~h}$. Cells were 
then cultured in DMEM containing $20 \mathrm{~mL} / \mathrm{L}$ FBS for 4 days to induce myotube differentiation. Following differentiation induction, cells were treated with the indicated concentrations of test samples for $2 \mathrm{~h}$. Glucose uptake was estimated using a glucose uptake colorimetric assay kit (Biovision, Milpitas, CA, USA) according to the manufacture's instructions.

\section{RESULTS and DISCUSSION}

\subsection{Weight and structure of the isolated compounds}

The isolated compounds were elucidated as (+)catehin, (-)-epicatechin, taxifolin, taxifolin-3'-O- $\beta$-D(+)-glucose and $\rho$-courmaric acid (Fig. 1) and the weight of the isolated compounds was indicated in Table 2.

\subsection{Evaluation of $\beta$-cells insulin secretion}

\subsubsection{Cell viability}

The cytotoxicities of the fractions of Korean red pine
Table 2. Weight of the isolated compounds

\begin{tabular}{cr}
\hline Compounds & \multicolumn{1}{c}{ Weight } \\
\hline \hline (+)-catechin & $469.8 \mathrm{mg}$ \\
(-)-epicatechin & $2.2 \mathrm{mg}$ \\
taxifolin & $15.4 \mathrm{mg}$ \\
taxifolin-3'-O- $\beta$-D-(+)-glucose & $321.2 \mathrm{mg}$ \\
$\rho$-courmaric acid & $18.5 \mathrm{mg}$ \\
\hline
\end{tabular}

extracts and the isolated compounds on HIT-T15 cells were tested by MTT assay.

The crude extract indicated $97 \%$ of cell viability at $5 \mu \mathrm{g} / \mathrm{ml}$ of concentration, but the higher than $1 \mu \mathrm{g} / \mathrm{ml}$ showed cytotoxicity (Fig. 2). Kim et. al. (2018) reported that Korean red pine inner bark extracts indicated 100 $\%$ of cell viability at $10 \mu \mathrm{g} / \mathrm{ml}$ of concentration on neuron-like PC-12 cells and Lee et al. (2013) also reported that PineXol showed $100 \%$ of cell viability up to $200 \mu \mathrm{g} / \mathrm{ml}$ of concentration on mature 3T3-L1 cells. Both of EtOAc and $\mathrm{H}_{2} \mathrm{O}$ soluble fractions gave $100 \%$ of cell viability up to $50 \mu \mathrm{g} / \mathrm{m} \ell$, but in the higher concentration, EtOAc soluble fraction indicated

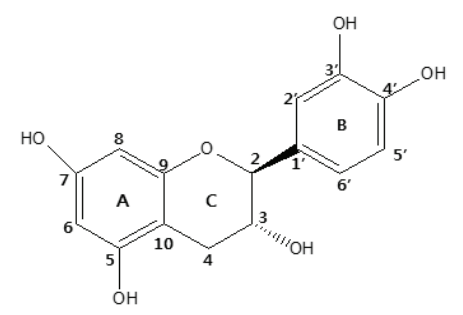

(+)-catechin

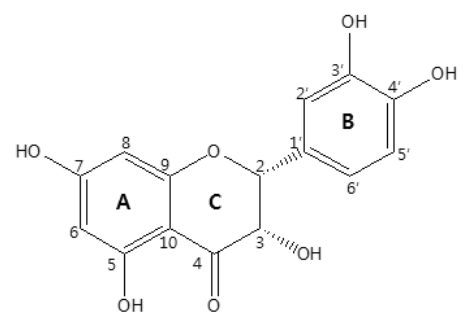

(-)-epicatechin

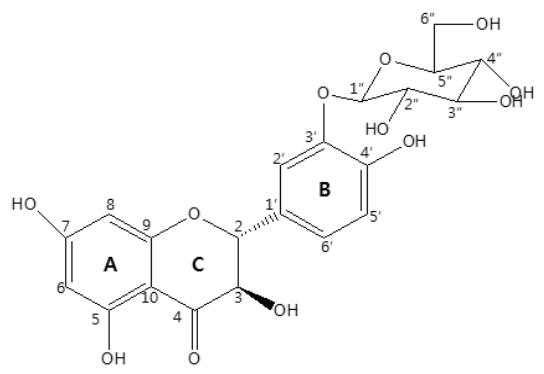

taxifolin-3'-O- $\beta$-D-(+)-glucose

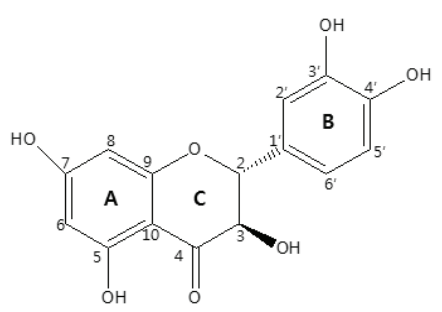

taxifolin

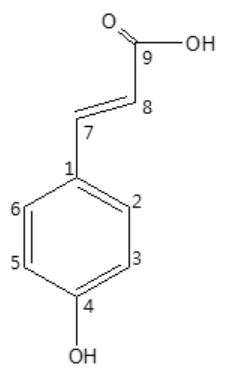

$\rho$-coumaric acid

Fig. 1. Chemical structures of isolated compounds. 


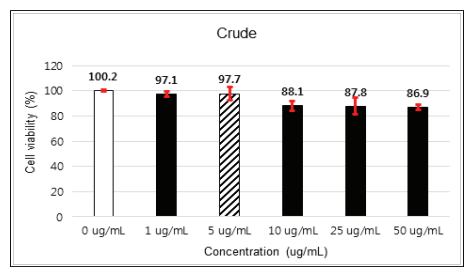

Fig. 2. Effects of crude on the viability of HIT-T15 cells.

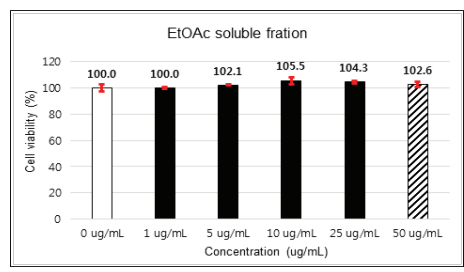

Fig. 3. Effects of EtOAc soluble fraction on the viability of HIT -T15 cells.

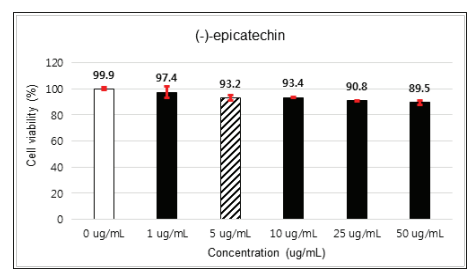

Fig. 6. Effects of (-)-epicatechin on the viability of HIT-T15 cells.

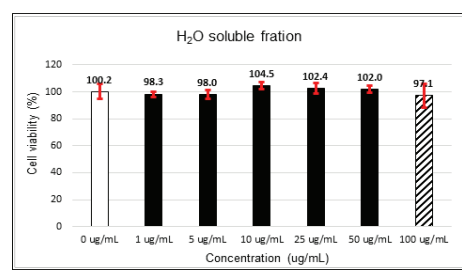

Fig. 4. Effects of $\mathrm{H}_{2} \mathrm{O}$ soluble fraction on the viability of HIT -T15 cells.

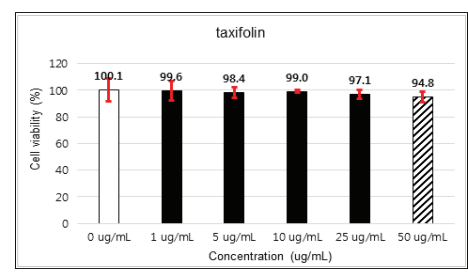

Fig. 7. Effects of taxifolin on the viability of HIT-T15 cells.

the viability of HIT-T15 cells.

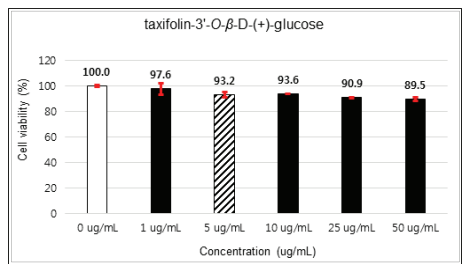

Fig. 8. Effects of taxifolin- $3^{\prime}-O-\beta$-D-(+)-glucose on the viability of HIT-T15 cells.

cytotoxicity (Fig. 3 and 4).

$(+)$-catechin showed $100 \%$ of cell viability up to $100 \mu \mathrm{g} / \mathrm{m} \ell$ of concentration. (-)-epicatechin and taxifolin-3'-O- $\beta$-D-(+)-glucose gave $93 \%$ of cell viability at $5 \mu \mathrm{g} / \mathrm{ml}$ of concentration, but indicated cytotoxicity in the higher (Figs. 5, 6 and 8). Taxifolin and $\rho$-coumaric acid gave almost $100 \%$ of cell viability up to $25 \mu \mathrm{g} / \mathrm{ml}$ of concentration and more than $90 \%$ of cell viability at $25 \mu \mathrm{g} / \mathrm{ml}$ of concentration (Figs. 7 and 9). Based on these results, the following tests were done within the range of nontoxic concentration on HIT-T15 cells.

\subsection{2. $\beta$-cells insulin secretion}

The variations of $\beta$-cells insulin secretion were

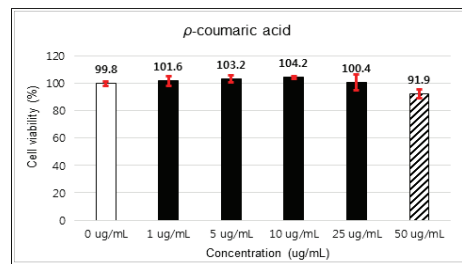

Fig. 9. Effects of $\rho$-coumaric acid on the viability of HIT-T15 cells.

checked by the addition concentrations of the crude, fractions and isolated compounds of Korean red pine inner bark extracts.

The crude showed $116 \%$ of $\beta$-cells insulin secretion at $5 \mu \mathrm{g} / \mathrm{ml}$ of concentration, but EtOAc and $\mathrm{H}_{2} \mathrm{O}$ soluble fractions did not indicate any significant difference (Fig. 10, 11 and 12). (+)-catechin indicated $98.3 \%$ at 25 $\mu \mathrm{g} / \mathrm{m} \ell, 102 \%$ at $50 \mu \mathrm{g} / \mathrm{ml}$, and $99 \%$ at $100 \mu \mathrm{g} / \mathrm{m \ell}$ without any variations by the concentration change (Fig. 13). (-)-epicatechin showed $110 \%$ at $1.25 \mu \mathrm{g} / \mathrm{ml}$ and $113 \%$ at $2.5 \mu \mathrm{g} / \mathrm{ml}$ (Fig. 14). Taxifolin gave $109 \%$ at $1.25 \mu \mathrm{g} / \mathrm{ml}$ and $128 \%$ at $25 \mu \mathrm{g} / \mathrm{m} \ell$, but decreased to $118 \%$ at $50 \mu \mathrm{g} / \mathrm{ml}$ (Fig. 15). In taxifolin-3'-O- $\beta$ -D-(+)-glucose, $\beta$-cells insulin secretion was $107 \%$ at 


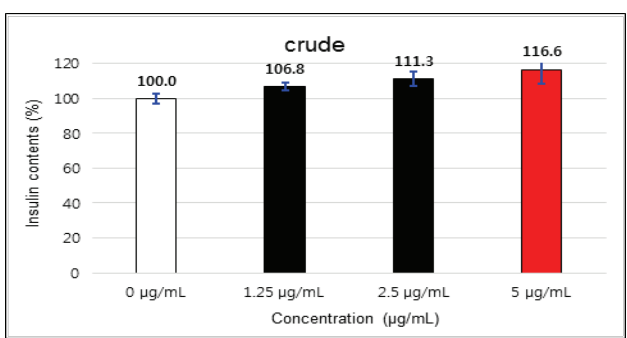

Fig. 10. Insulin secretion of HIT-T15 treated with the crude.

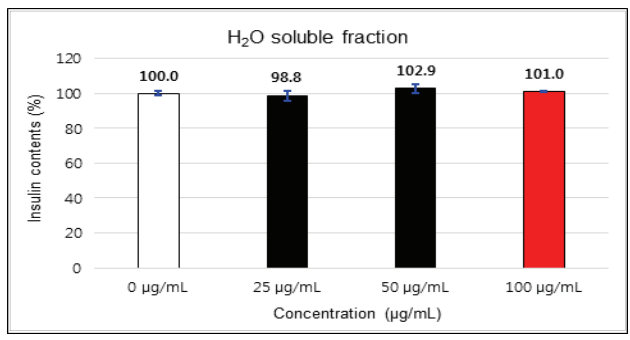

Fig. 12. Insulin secretion of HIT-T15 treated with the $\mathrm{H}_{2} \mathrm{O}$ soluble fraction.

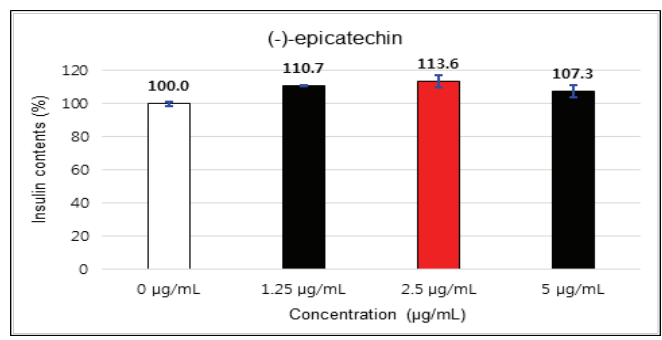

Fig. 14. Insulin secretion of HIT-T15 treated with (-)-epicatechin.

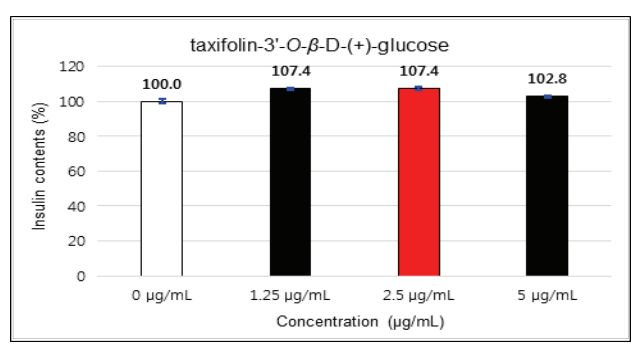

Fig. 16. Insulin secretion of HIT-T15 treated with taxifolin-3'-O- $\beta$-D-(+)-glucose.

$1.25 \mu \mathrm{g} / \mathrm{m} \ell$ and $2.5 \mu \mathrm{g} / \mathrm{m} \ell$, but had no significant difference compare to the control (Fig. 16). $\rho$-coumaric acid showed $117 \%$ at $12.5 \mu \mathrm{g} / \mathrm{m \ell}$ and $112 \%$ at 25

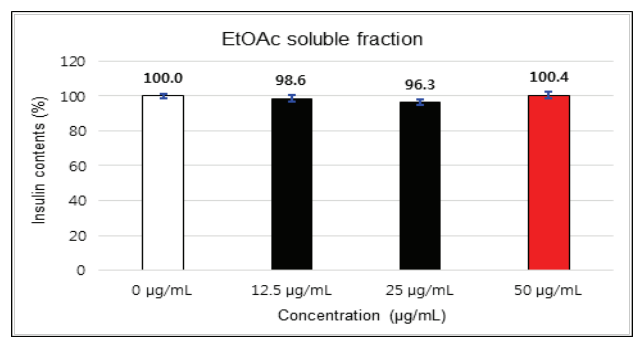

Fig. 11. Insulin secretion of HIT-T15 treated with the EtOAc soluble fraction.

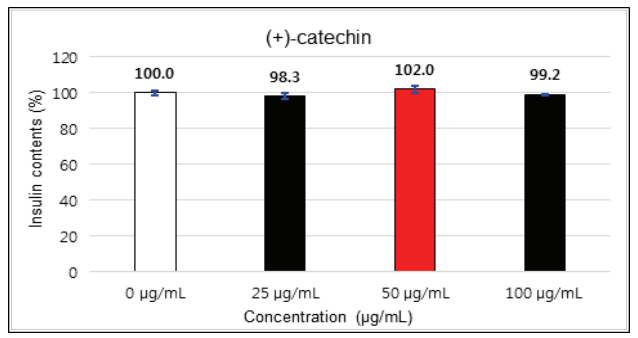

Fig. 13. Insulin secretion of HIT-T15 treated with (+)-catechin.

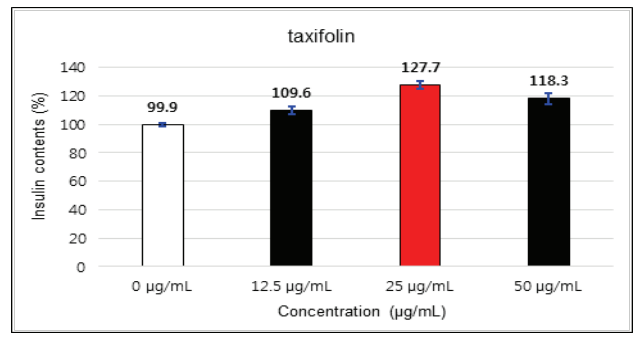

Fig. 15. Insulin secretion of HIT-T15 treated with taxifolin.

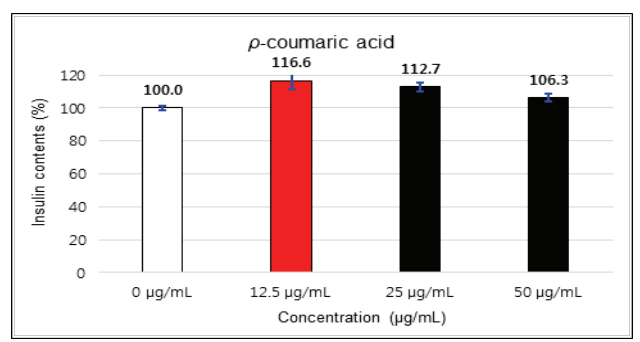

Fig. 17. Insulin secretion of HIT-T15 treated with $\rho$-coumaric acid.

$\mu g / m \ell$ (Fig. 17). Based on the above results, the Korean pine inner bark extracts did not improve the insulin secretion of pancreatic cells. 


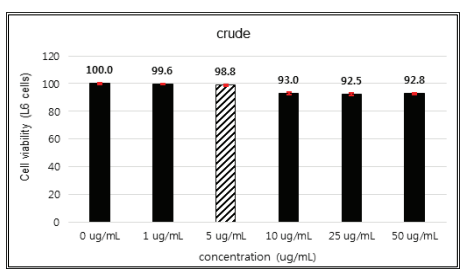

Fig. 18. Effects of crude on the viability of L6 cells.

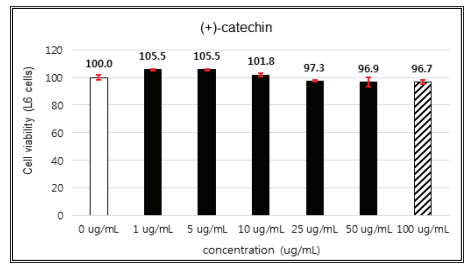

Fig. 21. Effects of $(+)$-catechin on the viability of L6 cells.

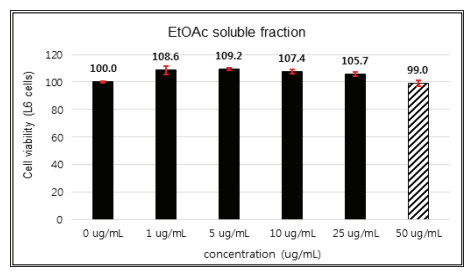

Fig. 19. Effects of EtOAc soluble fraction on the viability of L6 cells.

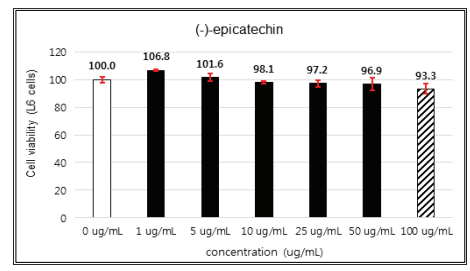

Fig. 22. Effects of (-)-epicatechin on the viability of L6 cells.

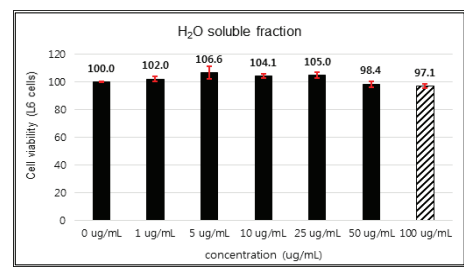

Fig. 20. Effects of $\mathrm{H}_{2} \mathrm{O}$ soluble fraction on the viability of L6 cells.

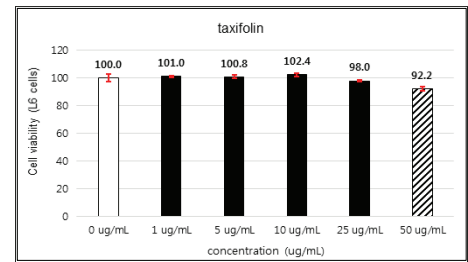

Fig. 23. Effects of taxifolin on the viability of L6 cells.

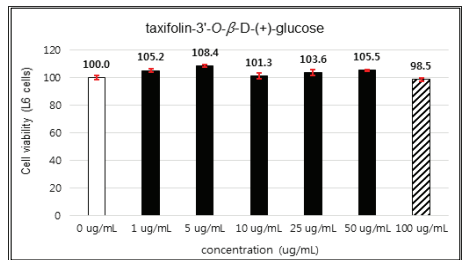

Fig. 24. Effects of taxifolin-3'-O- $\beta$-D-(+)glucose on the viability of L6 cells.

\subsection{Evaluation of glucose uptake activity in skeletal muscle cells}

\subsubsection{Cell viability}

The cytotoxicities of the fractions of Korean red pine extracts and the isolated compounds on L6 cells were tested by MTT assay using 0, 1, 5, 10, 25, 50 and $100 \mu \mathrm{g} / \mathrm{ml}$ of treating concentration.

The cytotoxicities of the fractions of Korean red pine extracts and the isolated compounds on L6 cells were tested by MTT assay using 0, 1, 5, 10, 25, 50 and $100 \mu \mathrm{g} / \mathrm{ml}$ of treating concentration.

\subsubsection{Glucose uptake activity}

The glucose uptake activities were checked by the concentrations of the crude, fractions and isolated

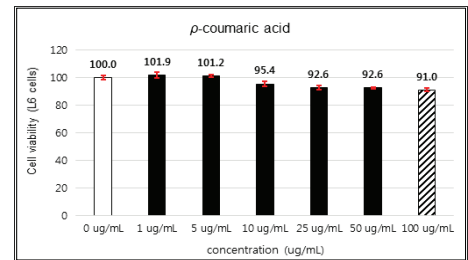

Fig. 25. Effects of $\rho$-coumaric acid on the viability of L6 cells.

compounds of Korean red pine inner bark extracts.

The activities of crude and $\mathrm{H}_{2} \mathrm{O}$ soluble fraction were increased as the concentration increases. The crude and $\mathrm{H}_{2} \mathrm{O}$ soluble fraction showed the greatest uptake 221 $\%$ at $5 \mu \mathrm{g} / \mathrm{m \ell}$ and $266 \%$ at $100 \mu \mathrm{g} / \mathrm{m \ell}$, respectively. These uptake activities are higher than $1 \mu \mathrm{M}$ insulin and similar to $2 \mathrm{mM}$ Metformin, one of commercial agents. EtOAc soluble fraction showed higher activities in all concentrations compare to $1 \mu \mathrm{M}$ insulin and was better than $2 \mathrm{mM}$ Metformin as $267 \%$ at $10 \mu \mathrm{g} / \mathrm{ml}$ (Fig. 26, 27 and 28).

The uptake activities of (+)-catechin and (-)-epicatehin were increased as the concentration increases. (+)-catechin was the highest as $264 \%$ at $100 \mu \mathrm{g} / \mathrm{ml}$ and (-)-epicatechin was 260 and $276 \%$ at $50 \mu \mathrm{g} / \mathrm{m \ell}$ 


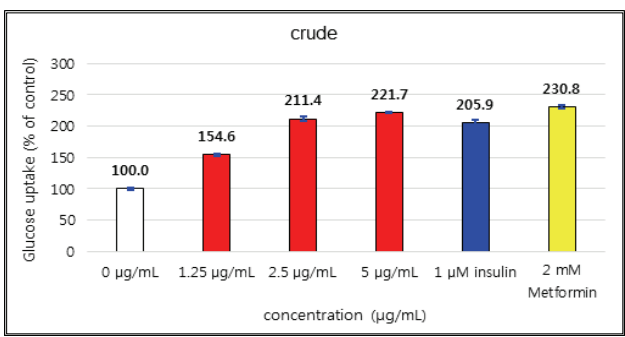

Fig. 26. Glucose uptake activities of the crude.

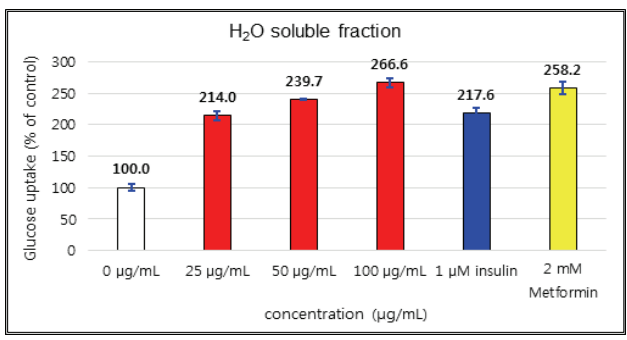

Fig. 28. Glucose uptake activities of the $\mathrm{H}_{2} \mathrm{O}$ soluble fraction.

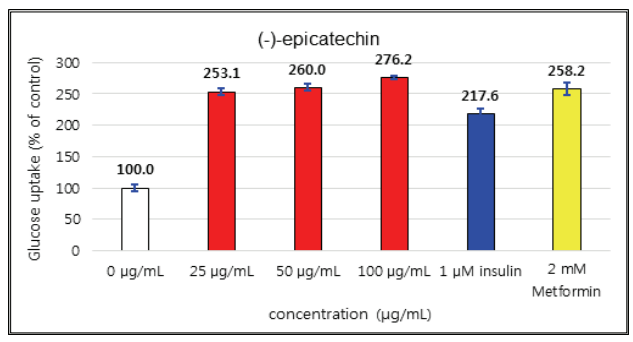

Fig. 30. Glucose uptake activities of (-)-epicatechin.

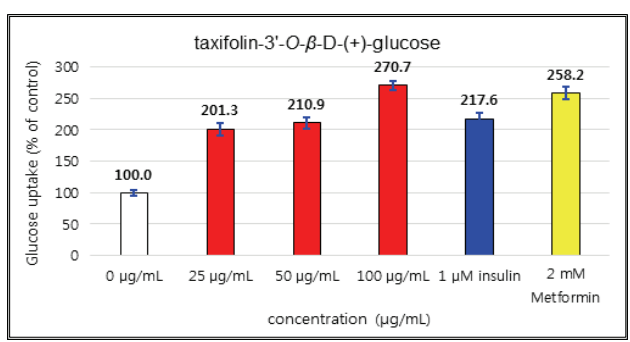

Fig. 32. Glucose uptake activities of taxifolin-3' -O- $\beta$-D-(+)-glucose.

and $100 \mu \mathrm{g} / \mathrm{m} \ell$, respectively, indicating the higher potentials compare to $1 \mu \mathrm{M}$ insulin and $2 \mathrm{mM}$ Metformin (Fig. 29 and 30). These results are very similar to the report by Ho et al. (2017) that the glucose uptake

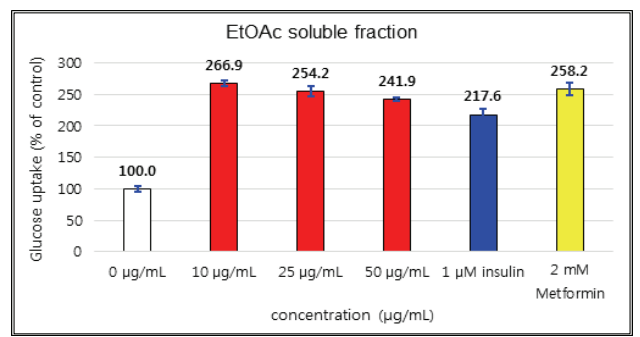

Fig. 27. Glucose uptake activities of the EtOAc soluble fraction.

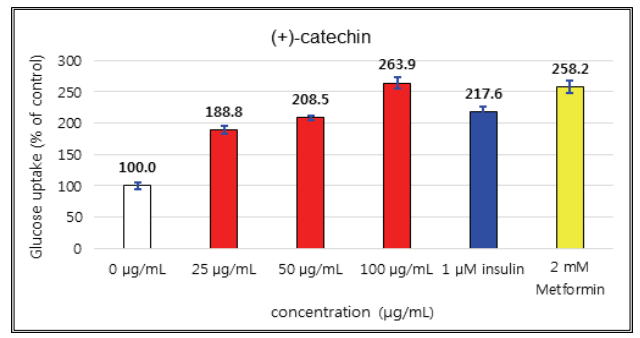

Fig. 29. Glucose uptake activities of (+)-catechin.

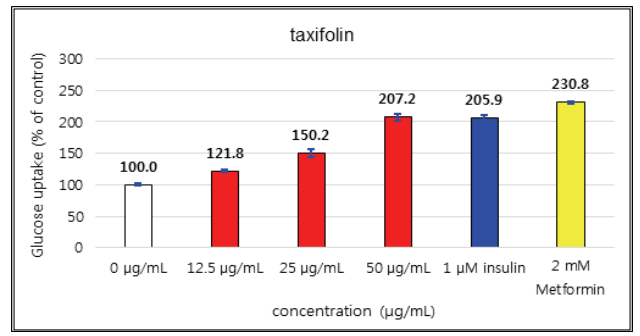

Fig. 31. Glucose uptake activities of taxifolin.

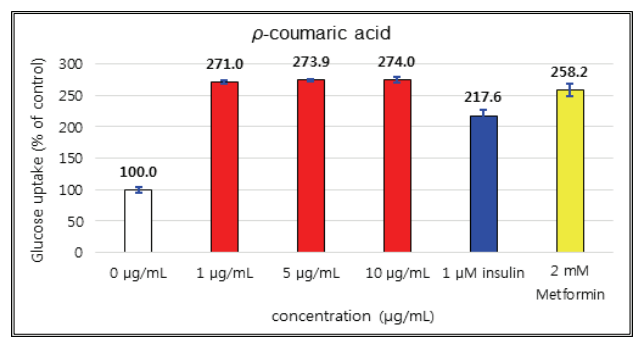

Fig. 33. Glucose uptake activities of $\rho$-coumaric acid.

activities of (+)-catechin and (-)-epicatehin on human myotubes and HepG2-cells were dependent on the concentration and that (-)-epicatehin was better than $(+)$-catechin. Taxifolin gave the glucose uptake acti- 
vities 122, 150, and $207 \%$ at $12.5 \mu \mathrm{g} / \mathrm{ml}, 25 \mu \mathrm{g} / \mathrm{ml}$, and $50 \mu \mathrm{g} / \mathrm{m} \ell$, respectively, similar to $1 \mu \mathrm{M}$ insulin (Fig. 31). Taxifolin-3'-O- $\beta$-D-(+)-glucose showed lower activity than $1 \mu \mathrm{M}$ insulin up to $50 \mu \mathrm{g} / \mathrm{ml}$ of concentration, but indicated better potential than $2 \mathrm{mM}$ Metformin as $270 \%$ at $100 \mu \mathrm{g} / \mathrm{ml}$ (Fig. 32). Finally $\rho$-coumaric acid showed higher glucose uptake activity than $270 \%$ in all concentrations, indicating the higher than $1 \mu \mathrm{M}$ insulin and $2 \mathrm{mM}$ Metformin (Fig. 33).

\section{CONCLUSION}

$\beta$-cells insulin secretion and glucose uptake activity in muscle cells for the evaluation of antidiabetic activity were checked on the crude, EtOAc and $\mathrm{H}_{2} \mathrm{O}$ soluble fraction of Korean red pine inner bark extracts, including 5 compounds isolated by column chromatography.

The cytotoxicity of the fractions of Korean red pine extracts and the isolated compounds on HIT-T15 and L6 cells were tested by MTT assay using 0, 1, 5, 10, 25, 50 and $100 \mu \mathrm{g} / \mathrm{ml}$ of treating concentration. Based on the cytotoxic results, the following tests were done within the range of nontoxic concentration on HIT-T15 and L6 cells.

The crude showed $\beta$-cells insulin secretion of 116 $\%$ at $5 \mu \mathrm{g} / \mathrm{ml}$ of concentration, but EtOAc and $\mathrm{H}_{2} \mathrm{O}$ soluble fractions did not indicate any significant difference. (+)-catechin did not indicate any significant variations by the concentration change. (-)-epicatechin was $113 \%$ at $2.5 \mu \mathrm{g} / \mathrm{m \ell}$ and taxifolin gave $128 \%$ at $25 \mu \mathrm{g} / \mathrm{ml}$, but decreased to $118 \%$ at $50 \mu \mathrm{g} / \mathrm{ml}$. Taxifolin-3'-O- $\beta$-D-(+)-glucose had no significant variations by the concentration change. $\rho$-coumaric acid indicated $117 \%$ at $12.5 \mu \mathrm{g} / \mathrm{ml}$ and $112 \%$ at $25 \mu \mathrm{g} / \mathrm{mg}$.

The glucose uptake activities were checked by the concentrations of the crude, fractions and isolated compounds of Korean red pine inner bark extracts.

The glucose uptake activities were $221 \%$ at $5 \mu \mathrm{g} / \mathrm{m} \ell$ in the crude and $266 \%$ at $100 \mu \mathrm{g} / \mathrm{ml}$ in $\mathrm{H}_{2} \mathrm{O}$ soluble fraction. These values are higher than $1 \mu \mathrm{M}$ insulin and similar to $2 \mathrm{mM}$ Metformin, one of commercial agents. EtOAc soluble fraction showed higher activities in all concentrations compare to $1 \mu \mathrm{M}$ insulin and was better than $2 \mathrm{mM}$ Metformin as $267 \%$ at $10 \mu \mathrm{g} / \mathrm{ml}$.

(+)-catechin was $264 \%$ at $100 \mu \mathrm{g} / \mathrm{ml}$ and (-)-epicatechin was 260 and $276 \%$ at $50 \mu \mathrm{g} / \mathrm{m \ell}$ and 100 $\mu \mathrm{g} / \mathrm{m} \ell$, respectively, indicating the higher potentials compare to $1 \mu \mathrm{M}$ insulin and $2 \mathrm{mM}$ Metformin. Taxifolin gave the activity of $207 \%$ at $50 \mu \mathrm{g} / \mathrm{ml}$, similar to $1 \mu \mathrm{M}$ insulin. Taxifolin-3'-O- $\beta$-D-(+)-glucose indicated better potential than $2 \mathrm{mM}$ Metformin as 270 $\%$ at $100 \mu \mathrm{g} / \mathrm{ml}$. $\rho$-coumaric acid showed higher glucose uptake activity than $270 \%$ in all concentrations, indicating the better activities than $1 \mu \mathrm{M}$ insulin and 2 $\mathrm{mM}$ Metformin.

Based on the above results, the crude, EtOAc soluble fraction, $\mathrm{H}_{2} \mathrm{O}$ soluble fraction, and isolated compounds of Korean red pine extracts did not show any significant results on the insulin secretion of pancreas $\beta$-cells except taxifolin, but indicated the significant differences on the glucose uptake activities. Korean pine inner bark extracts had a good potential to control blood glucose using glucose uptake activity. Therefore, Korean red pine inner bark extracts can be one of useful natural resources to substitute a synthetic hypoglycemic agent in the future.

\section{ACKNOWLEDGMENT}

This study was supported by "R\&D Program for Forest Science Technology (Project No. 2013070B101819-AA03)" of Korea Forest Service and partially by 2017 Research Grant from Kangwon National University (No. 520170355).

\section{REFERENCES}

Ahn, B.T., Oh, K.J., Park, S.K., Chung, S.G., Cho, E.H. 
Kim, J.G., Ro J.S., Lee, K.S. 1996. Phenolic compounds from leaves of Spiraea salicifolia. Korean Journal of Pharmacognosy 27(3): 178-183. Aviram, M. 2000. Review of human studies on oxidative damage and antioxidant protection related to cardiovascular diseases. Free Radical Research 33: 85-97.

Choi, Y.Y., Sohn, H.S., Shin, H.T. 2010. Clinical benefit of delf-Monitoring of blood glucose in non-insulin treated patients with type 2 diabetes : A systematic review and meta-analysis. Korean Journal of Clinical Pharmacy 20(3): 189-192.

Denizot, F., Lang, R. 1986. Rapid colorimetric assay for cell growth and survival: modification of the tetrazolium dye procedure giving improved sensitivity and reliability. Journal of Immunological Methods 89: 271-277.

Eizirik, D.L., Mandrup-Poulsen T. 2001. A choice of death-the signal-transduction of immune-mediated $\beta$-cell apoptosis. Diabetologia 44: 2115-2133.

Erben, B., Benjamin, H.S.L. 2000. Pycnogenol inhibits generation of inflammatory mediators in macrophage. Nutrition Research 20: 249-259.

Evans, J.L., Goldfine, I.D., Maddux, B.A., Grodsky, G.M. 2002. Oxidative stress and stress-activated signaling pathways: a unifying hypothesis of type 2 diabetes. Endocrine Reviews 23(5): 599-622.

Fabio, V., Kobuchi, H., Lester, P. 1998. Procyanidins extracted from Pinus maritima (Pycnogenol $\mathbb{R}$ ) : Scavengers of free radical species and modulators of nitrogen monoxide metabolism in activated murine RAW 264.7 macrophages. Free Radical Biology and Medicine 24: 1120-1129.

Foo, L., Karchesy, J.J. 1989. Procyanidin dimers and trimers from Douglas fir inner bark. Phytochemistry 28(6): 1743-1747.

Ham, Y.H., Bae, Y.S. 1995, Flavonoids extractives of Populus albaglandulosa. Journal of the Korean Wood Science and Technology 23(2): 94-99
Harborne, J.B., Mabry, T.J. 1982. The flavonoid: advances in research, Chapman and Hall Ltd.

Heo, S.J., Hwang, J.Y., Choi, J.I., Han, J.S., Kim, H.J., Jeon, Y.J. 2009. Diphlorethohydroxycarmalol isolated from Ishige okamurae, a brown algae, a potent alpha-glucosidase and alpha-amylase inhibitor, alleviates postprandial hyperglycemia in diabetic mice. European Journal of Pharmacology 615(1-3): 252-256.

Ho, G.T.T., Kase, E.T., Wangensteen, H3., Barsett, H. 2017. Effect of phenolic compounds from elderflowers on glucose- and fatty acid uptake in human myotubes and HepG2-cells. Molecules 22(1): 1-15.

Jeong, M.J., Yang, J.Y., Choi, W.S., Kim, J.W., Kim, S.J., Park, M.J. 2017. Chemical Compositions and Antioxidant Activities of Essential Oil Extracted from Neolitsea aciculata (Blume) Koidz Leaves. Journal of the Korean Wood Science and Technology 45(1): 96-106.

Jung, J.Y., Yang, J.K., Lee, W.H. 2017. Antioxidant and Safety Test of Natural Extract of Quercus mongolica. Journal of the Korean Wood Science and Technology 45(1): 116-125.

Kim, B.H., Son, S.M. 2006. Mechanism of developing diabetic vascular complication by oxidative stress. journal of the Korean Endocrine Society 21(6): 448-459.

Kim, I.H., Ko, Y.J., Choi, I.D., Kim, Y.G., Ryu, C.H., Shin, K.H. 2012. Antioxidative activities of pine needles and quality characteristics of Korean wheat noodle with pine needle powder. Journal of Agriculture \& Life Science 46(5): 127-136.

Kim, J.W., Im, S.B., Jeong, H.R., Jung, Y.S., Lee, I.I., Kim, K.J., Park, S.K., Kim, D.O. 2018. Neuroprotective effects of korean red pine (Pinus densiflora) bark extract and its phenolics. Journal of Microbiology and Biotechnology 28(5): 679-687. Kim, S.H., Lee, S.Y., Cho, S.M., Hong, C.Y., Park, S.Y., Park, M.J., Choi, I.G. 2017. Antioxidant 
activities of cryptomeria japonica leaves extracts by extraction methods. Journal of the Korean Wood Science and Technology 45(5): 495-510. Kim, T.W. 1996. Korean Tree. Kyohak. 28-36. Lee, Y.J., Han, O.T., Choi, H.S., Lee, B.Y., Chung. H.J., Lee, O.H. 2013. Antioxidant and antiadipogenic effects of PineXol. Korean Journal of Food Science and Technology 45(1): 97-103.

Liu, X., Wei, J., Tan, F., Zhou, S., Wurthwein, G., Rohdewald, P. 2004. Antidiabetic effec of pycnogenol ${ }^{\circledR}$ french maritime pine bark extract in patients with diabetes type $\amalg$. Life Sciences 75: 2505-2513. Miriam, C., Nils, W., Jonas, J.C., Anne, J., Sigurd, L. and Decio, L.E. 2005. Mechanisms of pancreatic $\beta$-cell death in type 1 and type 2 diabetes: many differences, few similarities. Diabetes 54: 97-107.

Novo, E., Parola, M. 2008. Redox mechanisms in hepatic chronic wound healing and fibrogenesis. Fibrogenesis Tissue Repair 1: 1-58.

Shinn, S.H., Min, H.J., Bae, Y.S. 2019. Phenolic compounds from japanese anise (Illicium anisatum L.) leaves. Journal of Korean Wood Science and Technology 47(1): 1-7.

Standl, E., Schnell, O. 2012. Alpha-glucosidase inhibitors cardiovascular considerations and trial evaluation. Diabetes and Vascular Disease Research 9(3): 163-169. 